\title{
Thyroid hormone modulation of brain in vivo tyrosine hydroxylase activity and kinetics in the female catfish Heteropneustes fossilis
}

\author{
R Chaube and $\mathbf{K} \mathbf{P}$ Joy \\ Department of Zoology, Banaras Hindu University, Varanasi-221005, India \\ (Requests for offprints should be addressed to K P Joy; Email: kpjoy@bhu.ac.in)
}

\begin{abstract}
In the female catfish Heteropneustes fossilis, administration of thyroxine $\left(\mathrm{T}_{4}\right), 1 \mu \mathrm{g} / \mathrm{g}$ body weight, i.p., in both gonadal resting and preparatory phases for 7,14 and 21 days caused hyperthyroidism, as evidenced from a duration-dependent significant increase in serum triiodothyronine $\left(\mathrm{T}_{3}\right)$, and of tyrosine hydroxylase $(\mathrm{TH})$ activity in telencephalon, hypothalamus-pituitary and medulla oblongata (Newman-Keuls' test; $P<0 \cdot 05)$. Hypothyroidism induced by adding $0.03 \%$ thiourea to aquarium water holding the catfish for 7,14 and 21 days decreased serum $T_{3}$ levels in a duration-dependent manner (Newman-Keuls' test; $P<0 \cdot 05$ ) and inhibited $\mathrm{TH}$ activity in the brain regions. $\mathrm{T}_{4}$ replacement in $21-$ day thiourea-treated fish restored and even elevated significantly serum $\mathrm{T}_{3}$ levels as well as brain $\mathrm{TH}$ activity in a duration-dependent manner. In general, the changes in enzyme activity were higher in the forebrain regions than medulla oblongata and in the resting phase
\end{abstract}

than preparatory phase. Kinetic studies by LineweaverBurk plots showed that the stimulatory effect following $\mathrm{T}_{4}$ administration and $\mathrm{T}_{4}$ replacement on $\mathrm{TH}$ activity was due to increased affinity of the enzyme for its cofactor (6,7-dimethyl-2-amino-4-hydroxy5,6,7,8-tetrahydropteridine), as evident from a significant decrease in apparent Michaelis-Menten constant $\left(K_{\mathrm{m}}\right)$ and an increase in apparent velocity maximum $\left(V_{\max }\right)$. The $\mathrm{TH}$ inhibition due to the thiourea treatment can be related to decreased affinity of the enzyme for its cofactor, as evident from a significant increase in apparent $K_{\mathrm{m}}$ value and a significant decrease in $V_{\max }$. These data clearly show that circulating levels of $\mathrm{T}_{4} / \mathrm{T}_{3}$ modulate brain $\mathrm{TH}$ activity by altering the kinetic properties of the enzyme, which, in turn, influence catecholaminergic activity and dependent functions.

Journal of Endocrinology (2003) 179, 205-215

\section{Introduction}

Thyroid hormone $\left(T_{3}\right)$ is a primary epigenetic factor influencing multiple events in neural development such as axonal maturation, neurite outgrowth, cell migration, myelin formation, etc. (Denver 1997, Oppenheimer \& Schwartz 1997). Apart from their well known feedback actions in the brain related to the regulation of thyrotrophin (TSH) secretion from the pituitary, thyroid hormones (thyroxine $\left(\mathrm{T}_{4}\right)$ and triiodothyronine $\left(\mathrm{T}_{3}\right)$ ) exert a crucial role in the overall neural activity of both central and peripheral nervous systems in vertebrates (Rastogi \& Singhal 1976, Ruiz-Marcos et al. 1994, Claustre et al. 1996). $T_{4}$ is transported into the brain, concentrated, retained and metabolised in discrete neural systems (Dratman et al. 1987, Schreiber et al. 1990). $\mathrm{T}_{3}$, the functional thyroid hormone, accounts for the major part of iodocompounds in the brain (80\%) and its concentration is generally maintained at a relatively stable level despite thyroid hormone deficiency or excess (Dratman et al. 1987). $\mathrm{T}_{3}$ receptors ( $\alpha$ and $\beta$ subtypes) are generally distributed in neurons, glial and ependymal cells (Puymirat et al. 1991).

Thyroid hormones have been demonstrated to influence the maturation and maintenance of the brain catecholamine (CA)-ergic system (Rastogi \& Singhal 1976, Claustre et al. 1996). Noradrenergic activity in the peripheral sympathetic nervous system and CA-ergic activity in the adrenal medulla are also dependent on the thyroid status; plasma noradrenaline increases in hypothyroid subjects (Valens \& Gripois 1990). Immunocytochemical studies have demonstrated the coexistence of both thyronergic ( $\mathrm{T}_{3}$-containing) and noradrenergic systems (locus coeruleus neurons and their targets) and $\mathrm{T}_{3}$ can act as a neurotransmitter/neuromodulator (Rozanov \& Dratman 1996, Gordon et al. 1999). Tyrosine hydroxylase (TH) is the rate-limiting step in CA biosynthesis and is influenced by the thyroid status (Kizer et al. 1978, Wang et al. 1989, Claustre et al. 1996, Evans et al. 1999); surgical thyroidectomy increases $\mathrm{TH}$ activity and $\mathrm{T}_{4}$ replacement restores it. However, hypothyroidism induced by propylthiouracil (PTU) decreases TH activity in the anterior 
part of the locus coeruleus and adrenal medulla and hyperthyroidism by $\mathrm{T}_{4}$ injection elevates it (Claustre et al. 1996).

In teleosts, investigations on brain $\mathrm{TH}$ are largely related to its use as a phenotypic marker for the CA-ergic system (Hornby \& Piekut 1990). In rainbow trout, TH activity was demonstrated in forebrain regions (Linard et al. 1996). Further, cDNA cloning and sequencing of TH have been demonstrated in the rainbow trout (Linard et al. 1998) and eel (Boularand et al. 1998). In our earlier studies, we have demonstrated seasonal, diurnal, regional and sexual differences in, and effects of environmental factors (photoperiod and temperature) as well as oestrogens on brain $\mathrm{TH}$ activity and kinetics in the catfish (Chaube \& Joy 2002, 2003). To the best of our knowledge, there are no studies relating to the role of thyroid hormones in the regulation of $\mathrm{TH}$ activity in non-mammals. In teleosts, the role of thyroid hormones in morphogenesis, development, growth, osmoregulation, migration, metabolism and reproduction are broadly defined (Eales 1993), but their involvement in specific functions of the brain is not demonstrated. $T_{3}$ is the functional thyroid hormone and is formed extrathyroidally, while $\mathrm{T}_{4}$ is involved in the feedback regulation of TSH secretion (Eales et al. 1993). As in mammals, the teleost brain is also a site for $\mathrm{T}_{4}$ and $\mathrm{T}_{3}$ deiodination (Plate et al. 2002).

In the present study, we demonstrated the effects of hyperthyroidism (by $\mathrm{T}_{4}$ administration), hypothyroidism (induced by thiourea) and $\mathrm{T}_{4}$ replacement on in vivo $\mathrm{TH}$ activity and kinetics in the brain regions of the female catfish Heteropneustes fossilis.

\section{Materials and Methods}

\section{Chemicals}

Catalase, L-tyrosine, 6,7-dimethyl-2-amino-4-hydroxy5,6,7,8-tetrahydropteridine $\left(\mathrm{DMPH}_{4}\right), \mathrm{BSA}$, Sephadex G-25 and $T_{4}$ were purchased from Sigma Chemical Company, St Louis, MO, USA. Sodium molybdate, 2-mercaptoethanol, sodium nitrite, thiourea and FolinCiocalteu reagent were purchased from E-Merck, Mumbai, India. RIA kits for $\mathrm{T}_{3}$ were purchased from Bhaba Atomic Research Centre, Mumbai, India.

\section{Fish collection and acclimatisation}

H. fossilis is a freshwater air-breathing catfish whose reproductive cycle can be divided into five phases: resting (September-January); preparatory or early vitellogenic (February-April); prespawning or late vitellogenic (MayJune); spawning (July-August); and post-spawning (September-October). The study was conducted in gonadal resting (December) and early vitellogenic (March) phases. Fish were collected from local fish markets in
Varanasi. Female fish weighing 35-45 g were selected and acclimatised in flow-through aquarium tanks under normal photoperiod and ambient temperature (resting phase: $10.5 \mathrm{~h}$ light: $13.5 \mathrm{~h}$ darkness, $18 \pm 2{ }^{\circ} \mathrm{C}$; vitellogenic phase: $11.5 \mathrm{~h}$ light: $12.5 \mathrm{~h}$ darkness, $22 \pm 2{ }^{\circ} \mathrm{C}$ ). They were fed minced goat liver daily. After 15 days of acclimatisation, the fish were used for various experiments as follows.

\section{Induction of hyperthyroidism}

Fish were divided into two groups of 25 each. Group 1 was injected i.p. on alternate days with $\mathrm{T}_{4}$ in a dose of $1 \mu \mathrm{g} / \mathrm{g}$ body weight (BW). $\mathrm{T}_{4}$ was dissolved in alkaline saline $(0.65 \% \mathrm{NaCl}$ containing $5 \mathrm{M} \mathrm{NaOH}$ to adjust the $\mathrm{pH}$ to $8 \cdot 1$ ) as vehicle. Group 2 was treated with the vehicle as control. After 7,14 and 21 days, five fish from each of the two groups were sampled at 1100-1200 h. Blood was collected by caudal puncture. The samples were centrifuged at $2000 \mathrm{~g}$ to collect serum, which was stored at $-70{ }^{\circ} \mathrm{C}$ for $\mathrm{T}_{3}$ assay. The fish were weighed, killed by decapitation and brains dissected out and stored at $-70{ }^{\circ} \mathrm{C}$ for $\mathrm{TH}$ assay. Ovaries were weighed and the gonadosomatic index $(\mathrm{GSI}=$ ovary weight $(\mathrm{g}) / \mathrm{BW} \times 100)$ calculated.

\section{Induction of hypothyroidism}

Since surgical thyroidectomy is not feasible in catfish due to the diffuse distribution of thyroid follicles in the pharyngeal floor, hypothyroidism was induced by thiourea, a thyroid hormone inhibitor and goitrogen. Fish were divided into two groups of 25 each. Group 1 was maintained in water containing $0.03 \%$ thiourea, which was replenished every day after feeding. Group 2 fish were maintained in dechlorinated tap water as control. At intervals of 7, 14 and 21 days, five fish each from the two groups were sampled at 1100-1200 h. Blood was collected for serum separation and stored at $-70{ }^{\circ} \mathrm{C}$ for $\mathrm{T}_{3}$ assay. The fish were weighed, killed by decapitation and brains dissected out and stored at $-70{ }^{\circ} \mathrm{C}$ for $24 \mathrm{~h}$ for $\mathrm{TH}$ assay. Ovaries were weighed for calculation of GSI.

\section{Reversal of hypothyroidism by $T_{4}$ replacement}

Fish were maintained in thiourea $(0.03 \%)$ for 21 days, as described above, and then divided into two groups and maintained in dechlorinated water. Group 1 was injected with $\mathrm{T}_{4}(1 \mu \mathrm{g} / \mathrm{g} \mathrm{BW})$, i.p., on alternate days. Group 2 was given vehicle only as control. Five fish from each of the two groups were sampled at intervals of 7, 14 and 21 days. Blood was collected for serum separation and serum stored at $-70{ }^{\circ} \mathrm{C}$ for $\mathrm{T}_{3}$ assay. The fish were weighed, 
killed by decapitation and brains dissected out and stored at $-70{ }^{\circ} \mathrm{C}$ for $24 \mathrm{~h}$ for $\mathrm{TH}$ assay. Ovaries were weighed for calculation of GSI.

\section{RIA of $T_{3}$}

Serum $\mathrm{T}_{3}$ level was assayed by RIA using the $\mathrm{T}_{3}$ kit. Serum $(50 \mu \mathrm{l})$ was incubated in duplicate with $0.1 \mathrm{ml}$ ${ }^{125} \mathrm{I}_{-} \mathrm{T}_{3}$ and $0 \cdot 1 \mathrm{ml}$ antiserum at $37^{\circ} \mathrm{C}$ for $3 \mathrm{~h}$ at room temperature. After incubation, $1.0 \mathrm{ml}$ of $\mathrm{PEG}-\mathrm{second}$ antibody (polyethylene glycol, 6\% w/v+goat anti-rabbit antibody) was added, mixed by vortexing and centrifuged at $2000 \mathrm{~g}$ for $20 \mathrm{~min}$ at $4{ }^{\circ} \mathrm{C}$. The supernatant was decanted and the pellet dried. Radioactivity was measured in a gamma counter (Beckman DP5000; Beckman Instruments Inc., Fullerton, CA, USA). For standard curve preparations, different concentrations of $\mathrm{T}_{3}(0 \cdot 15,0 \cdot 3,0 \cdot 6$, $1 \cdot 2,2.4 \mathrm{ng} / \mathrm{ml}$ ) provided with the kit were processed in the same manner as the plasma samples. The percentage of $\mathrm{B} / \mathrm{B}_{0}\left(\mathrm{~B}=\right.$ count rate for each sample, $\mathrm{B}_{0}=$ count rate for non-specific binding sample) was calculated and the standard curve was plotted using different standard concentrations of $\mathrm{T}_{3}$ vs percentage of $\mathrm{B} / \mathrm{B}_{0}$ on a logit-log scale. From the standard curve, $\mathrm{T}_{3}$ concentration of the sample was determined and expressed in $\mathrm{ng} / \mathrm{ml}$. All the samples were assayed from a single RIA kit. The minimum sensitivity of the assay was $0 \cdot 24 \mathrm{ng} / \mathrm{ml}$. The intra-assay coefficient of variation (determined from five standard curve assays) was $6 \%$.

\section{TH activity}

Brains were thawed and dissected out immediately on ice. The telencephalon (excluding olfactory tract and bulb), and hypothalamus along with pituitary and medulla oblongata were separated as described earlier (Chaube \& Joy 2002). Tissues were homogenised in $1 \mathrm{ml} 30 \mathrm{mM}$ sucrose containing $10 \mathrm{mM}$ Tris- $\mathrm{HCl}$ buffer $(\mathrm{pH} \mathrm{7.3)}$ in a PotterElvehjem homogeniser with a loose-fitting Teflon pestle. The rotor speed was 300-500 r.p.m. and the pestle was taken up and down four or five times. The homogenate was centrifuged at $105000 \mathrm{~g}$ for $1 \mathrm{~h}$ and passed through Sephadex G-25 column (1 ml column, flow rate $1 \mathrm{ml} /$ $40 \mathrm{~min})$ at $4{ }^{\circ} \mathrm{C}$ to remove endogenous CAs. The eluate containing $\mathrm{TH}$ activity was stored up to 1 week at $-20{ }^{\circ} \mathrm{C}$ and used as the enzyme preparation for $\mathrm{TH}$ assay. Enzyme activity was not affected by storage up to 1 week (data not shown).

TH activity was measured by the method of Shiman et al. (1971). The incubation mixture contained $0.25 \mathrm{ml}$ L-tyrosine $(2 \mathrm{mM})$, potassium phosphate-buffered saline (PBS, 2.0 M, pH 6.2), $0.01 \mathrm{ml}$ catalase $(1 \mathrm{mg} / 3 \mathrm{ml}$ in PBS buffer), $0.05 \mathrm{ml} \mathrm{0.28} \mathrm{M} \mathrm{2-mercaptoethanol,} 0.05 \mathrm{ml}$ $6 \mathrm{mM} \mathrm{DMPH}_{4}$. The reaction mixture was incubated in a test tube at $30{ }^{\circ} \mathrm{C}$ for $25 \mathrm{~min}$. The reaction was stopped by adding $0.5 \mathrm{ml} 0.5 \mathrm{M} \mathrm{HCl}$. Freshly prepared nitritemolybdate reagent $(1 \mathrm{ml})$ was added to the mixture and
Table 1 Effects of $\mathrm{T}_{4}$, thiourea and $\mathrm{T}_{4}$ replacement on gonadosomatic index (means \pm S.E.M. in $g \%$ ) in the female catfish Heteropneustes fossilis in the vitellogenic phase. Comparisons were made with respective controls and duration groups

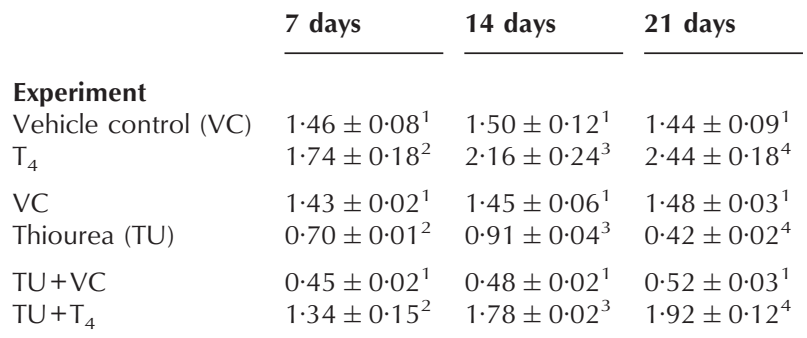

Values with the same superscripted numbers are not significant and those with different numbers are significant in each experiment (two-way ANOVA; Newman-Keuls' test).

allowed to stand for $5 \mathrm{~min}$. The colour was stable for 30 min. Half a millilitre of a $2 \mathrm{M} \mathrm{NaOH}$ solution was quickly added and mixed. Absorption was immediately determined at $510 \mathrm{~nm}$ in a UV-VIS 118 spectrophotometer (Systronics, Ahmedabad, India). To express enzyme activity, tissue protein content in each aliquot was measured by the method of Lowry et al. (1951) using BSA as standard. Enzyme activity was expressed as nmol L-dopa formed/mg protein per $\mathrm{h}$.

\section{Determination of kinetic parameters}

The Michaelis-Menten constants $\left(K_{\mathrm{m}}\right)$ and maximum velocity $\left(V_{\max }\right)$ of $\mathrm{TH}$ were determined from the intercepts on the $x$ - and $y$-axes respectively of double reciprocal Lineweaver-Burk plots with 1/[DMPH$\left.H_{4}\right](1-8 \mathrm{mM})$ or $1 /$ [L-tyrosine] $(0 \cdot 1-0.5 \mathrm{mM})$ as independent variable and $1 / \mathrm{TH}$ as dependent variable.

\section{Statistical analysis}

All data are expressed as means \pm S.E.M. The data were analysed by two-way ANOVA followed by NewmanKeuls' test $(P<0 \cdot 05)$.

\section{Results}

Effects of $T_{4}$ administration on GSI, serum $T_{3}$ levels and brain $\mathrm{TH}$

The GSI registered an overall significant effect (two-way ANOVA; $P<0 \cdot 001)$ after $\mathrm{T}_{4}$ administration in both vitellogenic (Table 1) and resting (data not shown) phases. The values increased significantly at all time points in both phases except on day 7 and 14 in the resting phase $\left(P<0 \cdot 05\right.$; Newman-Keuls' test). Serum $\mathrm{T}_{3}$ levels showed an overall significant effect (two-way ANOVA; $P<0 \cdot 001$ ) in both vitellogenic (Fig. 1B) and resting (data not shown) phases. The $\mathrm{T}_{3}$ levels increased significantly at all time points $(P<0 \cdot 05$; Newman-Keuls' test). 

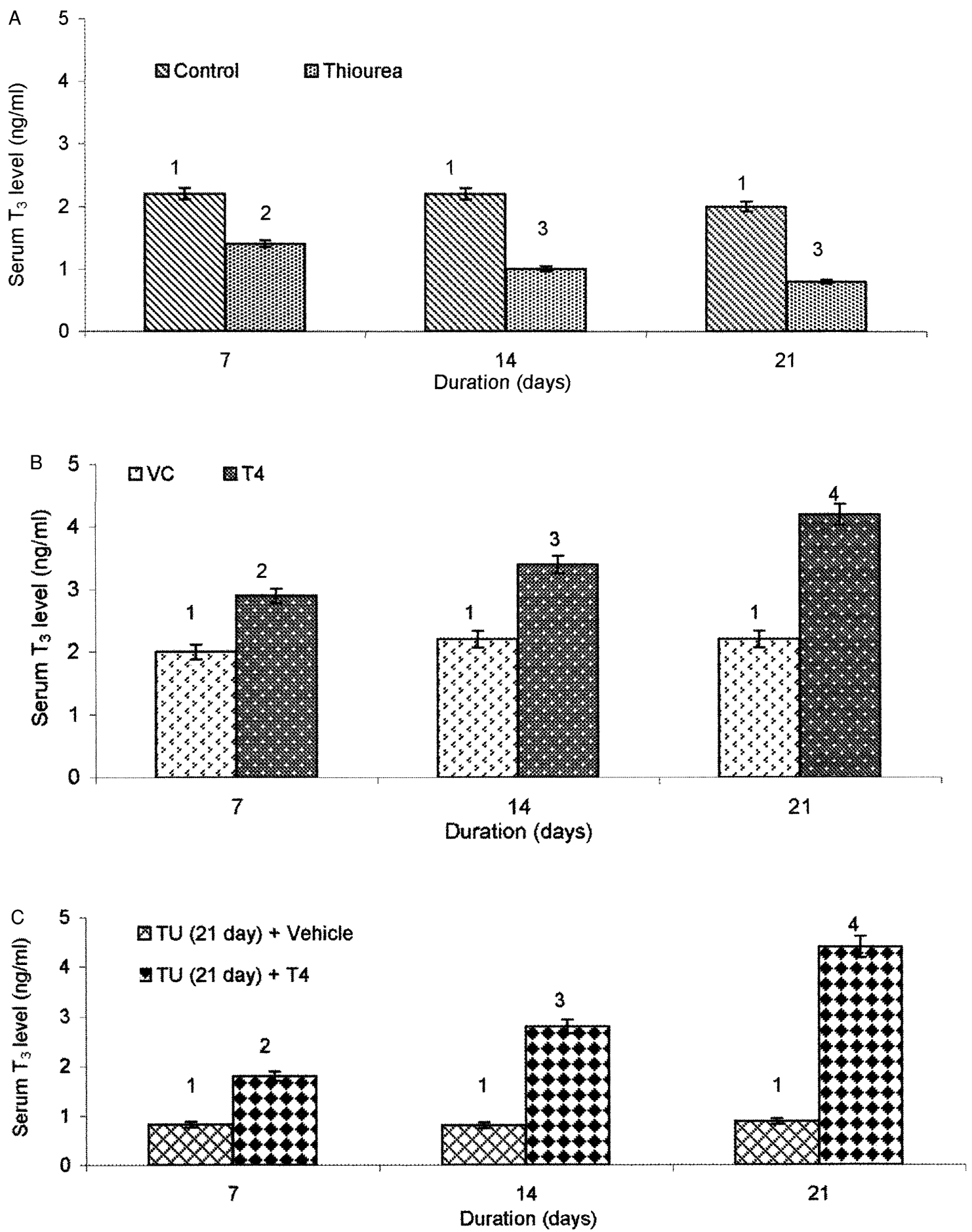

Figure 1 Effects of thiourea (TU) (A), $\mathrm{T}_{4}$ (B) and $\mathrm{T}_{4}$ replacement (C) on serum $\mathrm{T}_{3}$ levels in the female catfish Heteropneustes fossilis (means \pm S.E.M., $n=5)$ in the vitellogenic phase. Data were analysed by two-way ANOVA $(P<0 \cdot 001)$ and NewmanKeuls' test $(P<0 \cdot 05)$. Comparisons were made with respective controls and duration groups. Values with the same number are not significant and those with different numbers are significant in each experiment. $V C$, vehicle control. 

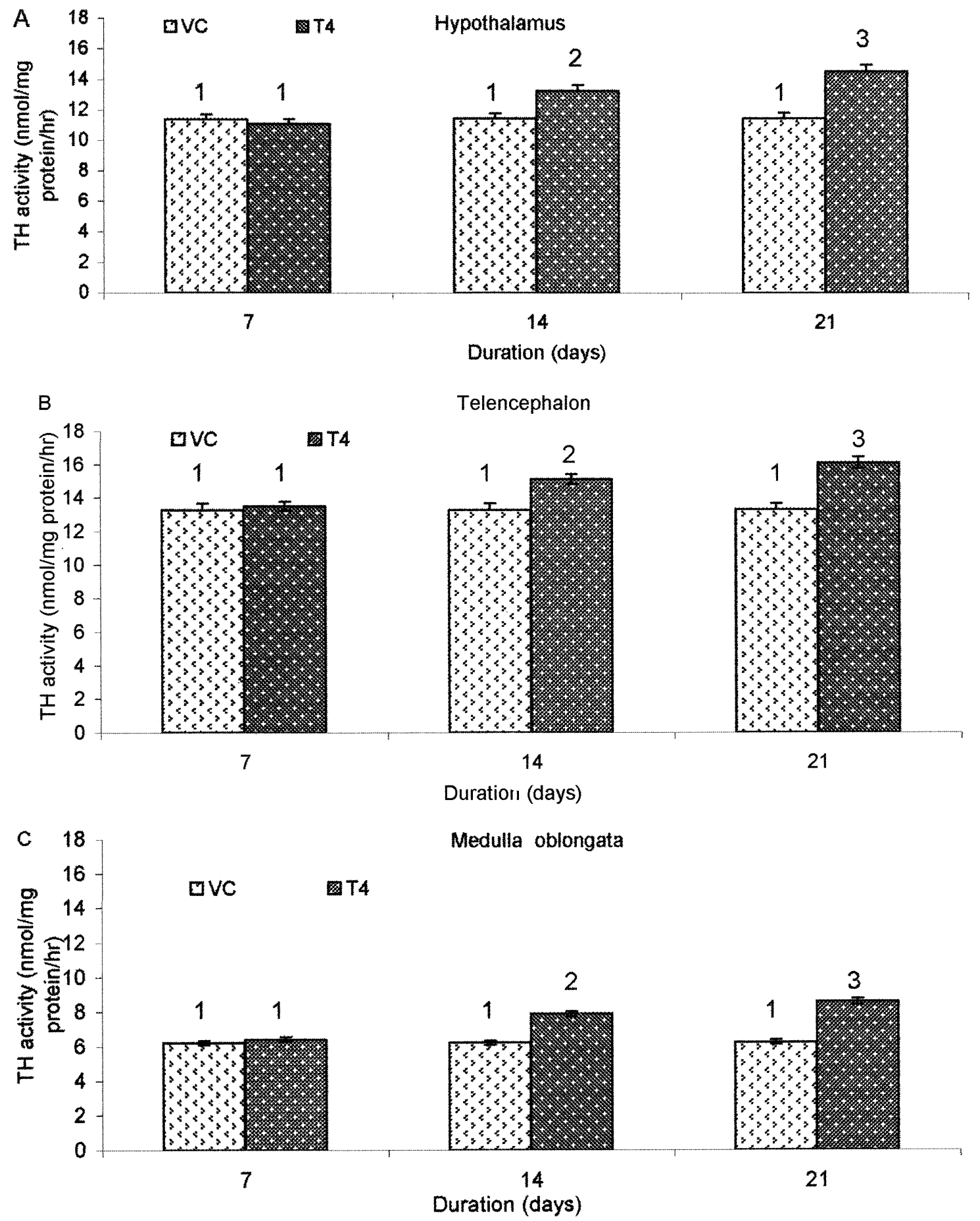

Figure 2 Effects of $\mathrm{T}_{4}$ treatment on brain TH activity in the female catfish Heteropneustes fossilis (means \pm S.E.M., $n=5$ ) in the vitellogenic phase. Data were analysed by two-way ANOVA $(P<0.001)$ and Newman-Keuls' test $(P<0 \cdot 05)$.

Comparisons were made with respective controls and duration groups. Values with the same number are not significant and those with different numbers are significant in each experiment. VC, vehicle control. 
Table 2 Effects of $\mathrm{T}_{4}$, thiourea and $\mathrm{T}_{4}$ replacement on apparent $K_{\mathrm{m}}$ and $V_{\max }$ (means \pm S.E.M.) of tyrosine hydroxylase for cofactor in brain regions of the female catfish Heteropneustes fossilis in the vitellogenic phase. The $K_{\mathrm{m}}$ and $V_{\max }$ values were calculated from Lineweaver-Burk plots. Data were analysed by two-way ANOVA $(P<0 \cdot 001)$ and Newman-Keuls' test $(P<0 \cdot 05)$. Comparisons were made with respective control groups and duration groups and were indicated by numbers $\left(K_{\mathrm{m}}\right)$ and letters $\left(V_{\max }\right)$

7 days

\begin{tabular}{ll}
\hline$K_{\mathrm{m}}$ \\
$(\mathrm{mM})$
\end{tabular}$\quad \begin{aligned} & V_{\max } \\
& (\mathrm{nmol} / \mathrm{mg} \text { protein/h) }\end{aligned}$

Hypothalamus

1. Vehicle control (VC)

$\mathrm{T}_{4}$

2. Control

Thiourea (TU)

3. $\mathrm{TU}+\mathrm{VC}$

$\mathrm{TU}+\mathrm{T}_{4}$

\section{Telencephalon}

1. VC

$\mathrm{T}_{4}$

2. Control

TU

3. $T U+V C$

$\mathrm{TU}+\mathrm{T}_{4}$

Medulla oblongata

1. VC

$\mathrm{T}_{4}$

2. Control

TU

3. $T U+V C$

$\mathrm{TU}+\mathrm{T}_{4}$
$20 \cdot 32 \pm 0 \cdot 98^{a}$

$20 \cdot 86 \pm 1 \cdot 80^{a}$

$20 \cdot 26 \pm 0 \cdot 92^{a}$

$20 \cdot 12 \pm 1 \cdot 08^{\mathrm{a}}$

$11 \cdot 62 \pm 1 \cdot 42^{\mathrm{a}}$

$12 \cdot 08 \pm 0 \cdot 86^{\mathrm{a}}$

$\begin{array}{ll}0 \cdot 15 \pm 0 \cdot 004^{1} & 22 \cdot 61 \pm 1 \cdot 70^{a} \\ 0 \cdot 14 \pm 0 \cdot 002^{1} & 22 \cdot 86 \pm 1 \cdot 82^{a} \\ 0 \cdot 14 \pm 0 \cdot 03^{1} & 22 \cdot 65 \pm 0 \cdot 86^{a} \\ 0 \cdot 35 \pm 0 \cdot 05^{2} & 22 \cdot 58 \pm 0 \cdot 40^{a} \\ 1 \cdot 16 \pm 0 \cdot 84^{1} & 10 \cdot 64 \pm 0 \cdot 48^{a} \\ 0 \cdot 84 \pm 0 \cdot 18^{2} & 11 \cdot 08 \pm 0 \cdot 28^{a}\end{array}$

$0 \cdot 26 \pm 0 \cdot 04^{1} \quad 12 \cdot 88 \pm 1 \cdot 12^{\mathrm{a}}$

$0 \cdot 20 \pm 0 \cdot 01^{1}$

$0 \cdot 28 \pm 0 \cdot 05^{1}$

$0 \cdot 30 \pm 0.03^{1}$

$0.60 \pm 0.07^{1}$

$0 \cdot 58 \pm 0.06^{1}$
$13 \cdot 24 \pm 0.61^{a}$

$12 \cdot 51 \pm 1 \cdot 28^{\mathrm{a}}$

$11 \cdot 22 \pm 1 \cdot 01^{\mathrm{a}}$

$5.63 \pm 0.81^{a}$

$6 \cdot 05 \pm 0 \cdot 82^{a}$
14 days

$K_{\mathrm{m}}$
$(\mathrm{mM})$

\begin{abstract}
$0 \cdot 22 \pm 0 \cdot 002^{1} \quad 20 \cdot 35 \pm 0 \cdot 24^{\mathrm{a}}$
$0 \cdot 10 \pm 0 \cdot 003^{2} \quad 22 \cdot 14 \pm 0 \cdot 72^{b}$

$0 \cdot 19 \pm 0 \cdot 01^{1} \quad 20 \cdot 30 \pm 1 \cdot 86^{\text {a }}$

$0 \cdot 58 \pm 0.03^{2} \quad 14.65 \pm 1 \cdot 05^{b}$

$0 \cdot 80 \pm 0.15^{1} \quad 11 \cdot 60 \pm 1 \cdot 68^{a}$

$0.42 \pm 0.04^{2} \quad 14.83 \pm 2 \cdot 02^{b}$
\end{abstract}

$0 \cdot 14 \pm 0.003^{1} \quad 22 \cdot 42 \pm 0 \cdot 24^{a}$

$0 \cdot 11 \pm 0.002^{1} \quad 24 \cdot 42 \pm 0 \cdot 62^{b}$

$0 \cdot 15 \pm 0.01^{1} \quad 22 \cdot 54 \pm 2 \cdot 02^{a}$

$0.98 \pm 0.08^{3} \quad 18.62 \pm 1 \cdot 80^{\mathrm{b}}$

$1 \cdot 10 \pm 0.02^{1} \quad 10 \cdot 66 \pm 0 \cdot 78^{a}$

$0 \cdot 62 \pm 0.03^{3} \quad 13 \cdot 75 \pm 1 \cdot 20^{b}$

$0 \cdot 24 \pm 0 \cdot 003^{1} \quad 12 \cdot 65 \pm 1 \cdot 26^{\mathrm{a}}$

$0 \cdot 15 \pm 0.002^{1} \quad 16 \cdot 24 \pm 0 \cdot 78^{b}$

$0 \cdot 26 \pm 0.02^{1} \quad 12 \cdot 58 \pm 1 \cdot 34^{a}$

$0.45 \pm 0.05^{2} \quad 8.42 \pm 0.75^{b}$

$0.56 \pm 0.08^{1} \quad 5 \cdot 61 \pm 1.06^{\mathrm{a}}$

$0 \cdot 30 \pm 0.05^{2} \quad 8.02 \pm 0.62^{b}$
21 days

\begin{tabular}{ll}
\hline$K_{\mathrm{m}}$ & $V_{\max }$ \\
$(\mathrm{mM})$ & $(\mathrm{nmol} / \mathrm{mg}$ protein/h)
\end{tabular}

$0 \cdot 20 \pm 0 \cdot 003^{1} \quad 20 \cdot 48 \pm 1 \cdot 54^{\mathrm{a}}$

$0 \cdot 09 \pm 0.001^{2} \quad 24 \cdot 60 \pm 1 \cdot 28^{\mathrm{c}}$

$0 \cdot 17 \pm 0.02^{1} \quad 20 \cdot 42 \pm 0.75^{a}$

$0 \cdot 82 \pm 0 \cdot 08^{3} \quad 12 \cdot 02 \pm 0 \cdot 98^{\mathrm{C}}$

$0.82 \pm 0.08^{1} \quad 11.65 \pm 1 \cdot 72^{a}$

$0 \cdot 30 \pm 0 \cdot 06^{3} \quad 18 \cdot 12 \pm 0 \cdot 28^{\mathrm{c}}$

$0 \cdot 14 \pm 0 \cdot 001^{1} \quad 22 \cdot 32 \pm 1 \cdot 42^{\mathrm{a}}$

$0 \cdot 05 \pm 0 \cdot 001^{1} \quad 26 \cdot 45 \pm 1 \cdot 18^{\mathrm{c}}$

$0 \cdot 16 \pm 0.02^{1} \quad 22 \cdot 48 \pm 1 \cdot 58^{a}$

$1 \cdot 28 \pm 0 \cdot 15^{4} \quad 10 \cdot 25 \pm 1 \cdot 02^{\mathrm{c}}$

$1 \cdot 12 \pm 0.03^{1} \quad 10 \cdot 68 \pm 1 \cdot 14^{\mathrm{a}}$

$0 \cdot 48 \pm 0 \cdot 01^{4} \quad 16 \cdot 18 \pm 1 \cdot 28^{\mathrm{c}}$

$0 \cdot 22 \pm 0.003^{1} \quad 12 \cdot 78 \pm 1 \cdot 12^{a}$

$0.12 \pm 0.001^{1} \quad 18.68 \pm 0.82^{\mathrm{c}}$

$0 \cdot 24 \pm 0 \cdot 08^{1} \quad 12 \cdot 45 \pm 1 \cdot 05^{\mathrm{a}}$

$0.58 \pm 0.06^{3} \quad 5 \cdot 42 \pm 0.86^{c}$

$0 \cdot 58 \pm 0 \cdot 10^{1} \quad 5 \cdot 68 \pm 0 \cdot 80^{\mathrm{a}}$

$0 \cdot 20 \pm 0 \cdot 02^{2} \quad 8 \cdot 62 \pm 0 \cdot 28^{\mathrm{c}}$

Values with the same superscripted numbers or letters are not significant and those with different numbers and letters are significant.

Brain TH activity showed an overall significant effect (two-way ANOVA; $P<0 \cdot 001$ ) in the vitellogenic phase (Fig. 2A-C) and resting phase (data not shown). In both phases, enzyme activity increased significantly on day 14 (except medulla oblongata) and on day 21 in all brain regions $(P<0 \cdot 05$; Newman-Keuls' test). The percentage increase on day 21 was lower in the vitellogenic phase (hypothalamus 27\%, telencephalon 21\%, and medulla oblongata 37\%) than resting phase (76, 69 and 53\% respectively).

The $\mathrm{T}_{4}$ administration produced overall significant effects on both apparent $K_{\mathrm{m}}$ and $V_{\max }$ of the enzyme for the cofactor in different brain regions (Table 2; two-way ANOVA; $P<0 \cdot 001)$. The $K_{\mathrm{m}}$ and $V_{\max }$ values did not vary significantly in the vehicle control groups over the duration in any of the brain regions. The $K_{\mathrm{m}}$ values decreased, and the $V_{\max }$ increased significantly in all brain regions on day 14 and $21(P<0 \cdot 05$; Newman-Keuls' test). In the resting phase, similar changes were found (data not shown) (two-way ANOVA; $P<0 \cdot 001$; Newman-Keuls' test; $P<0 \cdot 05)$.

\section{Effects of thiourea treatment on GSI, serum $T_{3}$ levels and brain TH}

The GSI showed an overall significant effect after thiourea treatment (two-way ANOVA; $P<0 \cdot 001$ ) in the vitello- genic phase (Table 1) and in the resting phase (data not shown). Newman-Keuls' analysis indicated significant inhibition $(P<0.05)$ at all times except on day 7 in the resting phase. The treatment resulted in an overall significant effect (two-way ANOVA; $P<0.001$ ) on serum $\mathrm{T}_{3}$ levels in both vitellogenic (Fig. 1A) and resting (data not shown) phases. The $\mathrm{T}_{3}$ levels decreased significantly at all time points compared with control values $(P<0 \cdot 05$; Newman-Keuls' test). The inhibition on day 7, 14 and 21 was $36,54.5$ and $60 \%$ respectively in the vitellogenic phase and 47,49 and $72 \%$ respectively in the resting phase.

The thiourea treatment produced an overall significant effect (two-way ANOVA; $P<0 \cdot 001$ ) on TH activity in different regions of the brain in both vitellogenic (Fig. $3 \mathrm{~A}-\mathrm{C}$ ) and resting (data not shown) phases. In both hypothalamus and telencephalon, enzyme activity decreased at all time points, but in the medulla oblongata, the decrease was significant only on day 14 and $21(P<0 \cdot 05$; Newman-Keuls' test). The percentage decrease on day 21 was 54\% (hypothalamus), 33\% (telencephalon) and 20\% (medulla oblongata) in the vitellogenic phase and 54.5, 61 and $21 \%$ respectively in the resting phase.

Apparent $K_{\mathrm{m}}$ and $V_{\max }$ of the enzyme for the cofactor showed overall significant effects (two-way ANOVA; $P<0.001)$ in both vitellogenic (Table 2) and resting (data not shown) phases. Since the treatment influenced both $K_{\mathrm{m}}$ and $V_{\max }$, the inhibition appeared to be of the mixed 

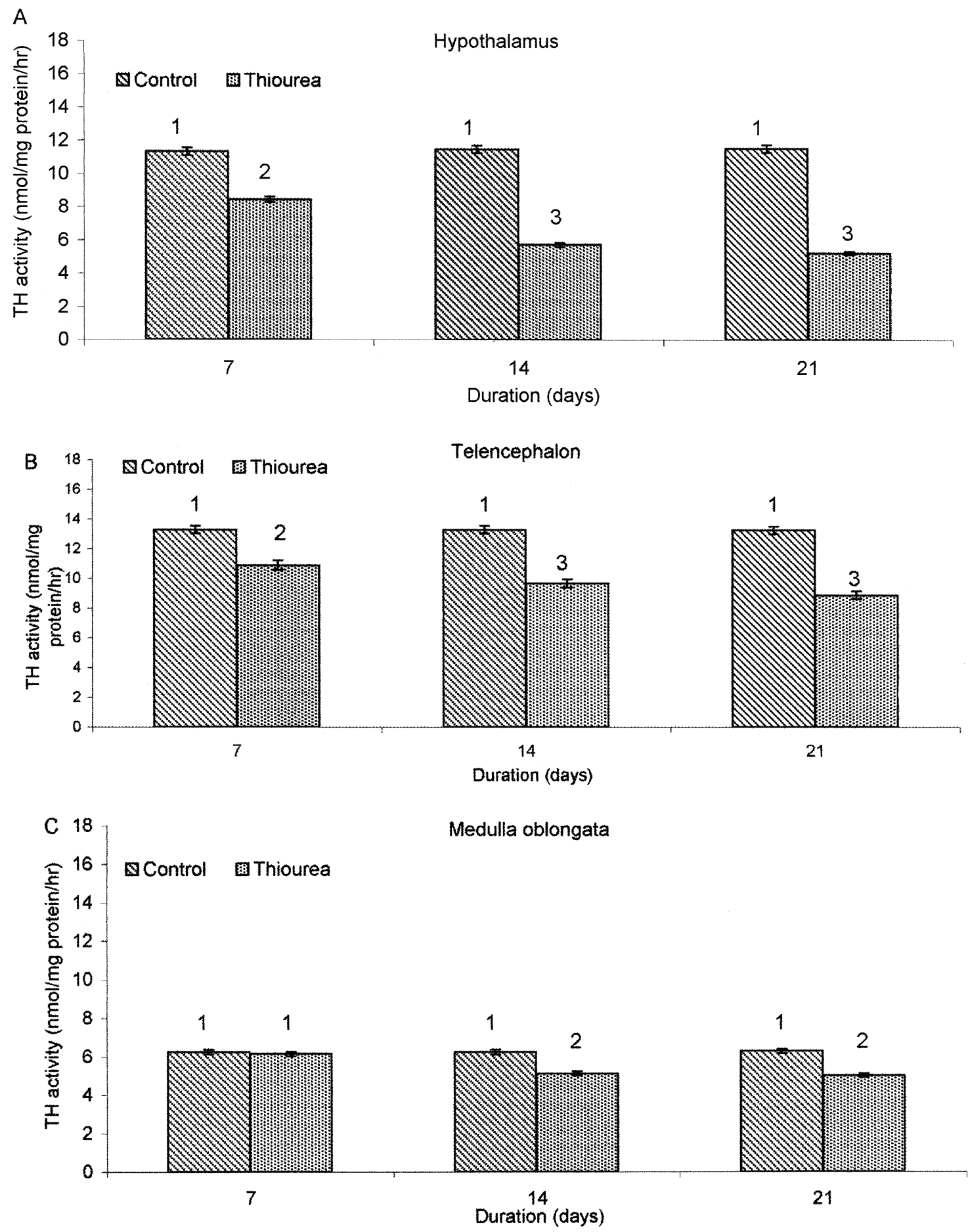

Figure 3 Effects of thiourea treatment on brain TH activity in the female catfish Heteropneustes fossilis (means \pm S.E.M., $n=5$ ) in the vitellogenic phase. Data were analysed by two-way ANOVA $(P<0 \cdot 001)$ and Newman-Keuls' test $(P<0 \cdot 05)$. Comparisons were made with respective controls and duration groups. Values with the same number are not significant and those with different numbers are significant in each experiment. 
or uncompetitive type. The $K_{\mathrm{m}}$ values increased, and the $V_{\max }$ decreased significantly over the duration of the treatment. In the thiourea-treated groups, the $K_{\mathrm{m}}$ and the $V_{\max }$ values did not change significantly in the hypothalamus and medulla oblongata on day 7 compared with the control groups $(P<0 \cdot 05$; Newman-Keuls' test). In the telencephalon, the $V_{\max }$ also did not vary significantly on day 7 . In the resting phase, similar changes were noticed.

\section{Effects of $T_{4}$ replacement on GSI, serum $T_{3}$ and brain $T H$}

The administration of $\mathrm{T}_{4}$ in 21-day thiourea-treated fish for 7, 14 and 21 days produced an overall significant effect (two-way ANOVA; $P<0.001$ ) on GSI in the vitellogenic (Table 1; treatment $F=6.25$, duration $F=16.85$ and interaction of both $F=26.65$ ) and resting (data not shown) phases. The GSI increased significantly at all time points $\left(P<0 \cdot 05\right.$; Newman-Keuls' test). Serum $\mathrm{T}_{3}$ levels showed a significant effect in both vitellogenic (Fig. 1C) and resting (data not shown) phases. The $\mathrm{T}_{3}$ levels increased significantly on day 7,14 and 21 and the percentage increase was $119 \cdot 5,250$ and $400 \%$ respectively in the vitellogenic phase and 215, 335 and 418\% respectively in the resting phase. In the control (thiourea+vehicle) groups, the $\mathrm{T}_{3}$ levels remained low even up to 21 days of the withdrawal.

Brain TH activity showed an overall significant effect (two-way ANOVA; $P<0.001$ ) after the replacement treatment in the vitellogenic and resting (data not shown) phases. The $T_{4}$ replacement caused a significant increase in $\mathrm{TH}$ activity in all brain regions at all times in the vitellogenic (Fig. 4A-C) and resting (data not shown) phases. The percentage increase on day 21 was much lower in the vitellogenic phase $(124 \%$, hypothalamus; $58.9 \%$, telencephalon; $21 \%$, medulla oblongata) than resting phase $(213 \%$, hypothalamus; $310 \%$, telencephalon; and $50 \%$, medulla oblongata).

$\mathrm{T}_{4}$ replacement produced overall significant effects (twoway ANOVA; $P<0 \cdot 001)$ on both apparent $K_{\mathrm{m}}$ and $V_{\max }$ values of the enzyme for the cofactor in the vitellogenic (Table 2) and resting (data not shown) phases. The values did not change significantly in the vehicle groups during the duration of the treatment. In the replacement groups, the values altered $\left(K_{\mathrm{m}}\right.$ decreased and $V_{\max }$ increased) significantly in both phases on day 14 and $21(P<0 \cdot 05$; NewmanKeuls' test). On day 7 , both the values are significantly different in the hypothalamus (resting phase) and the $K_{\mathrm{m}}$ values in the medulla oblongata (resting phase) and telencephalon (vitellogenic phase).

\section{Discussion}

The present study demonstrates clearly the involvement of thyroid hormones in the modulation of brain $\mathrm{TH}$ activity. The administration of $\mathrm{T}_{4}$ evoked significant brain $\mathrm{TH}$ activation detected after 2 weeks of treatment. These observations are in agreement with studies in mammals of a stimulatory effect of $T_{4} / T_{3}$ on the enzyme in developing or adult brains and adrenals (Rastogi \& Singhal 1976, Kato et al. 1982, Gripois \& Valens 1984, Valens \& Gripois 1990). However, conflicting reports of a lack of enzyme response, perhaps due to brain regional differences, short vs long treatment, developmental stage at which exposure was made, dosage, etc., are also available (Valens \& Gripois 1990, Claustre et al. 1996). In the catfish, $T_{4}$ administration resulted in hyperthyroidic conditions, as evident from the duration-dependent rise in serum $T_{3}$ levels, which may be responsible for the elevated brain $\mathrm{TH}$ activity. The response varied with the brain region, duration of the treatment and season. The magnitude of the response was higher in the forebrain regions than medulla oblongata and in the resting phase than vitellogenic phase. These differences may be due to regional differences in enzyme activity (Chaube \& Joy 2003) or the interplay of other factors like gonadal oestrogens on the brain-pituitary axis. The forebrain regions contain oestrogen feedback sites and the oestradiol $\left(\mathrm{E}_{2}\right)$ feedback is stronger in the vitellogenic phase than resting phase (Senthilkumaran \& Joy 1995). The increase in GSI suggests that hyperthyroidism caused a stimulation of ovarian activity. Since thyroid hormones modulate gonadal steroidogenesis (Cyr \& Eales 1988, Timmermans et al. 1997), the resulting strong $E_{2}$ feedback might have lessened the otherwise full-blown effect of $\mathrm{T}_{4} / \mathrm{T}_{3}$ in the vitellogenic phase (Chaube \& Joy 2002).

Hypothyroidism has long been linked to retardation of development, maturation and functions of the nervous system and causes mental ailment, motor dysfunction, behavioural changes, early neurodegenerative activity, etc. - some of these disorders have been related to impairment of CA metabolism (Evans et al. 1999, Kincaid 2001). Hypothyroidism caused tyrosinaemia (tyrosine accumulation) in the brain, adrenal, heart, etc. (Diarra et al. 1989) and the genetically hypothyroid mouse (non-functional thyroid due to defective TSH receptor) showed significantly fewer (40\%) dopamine (TH-positive) neurons in the substantia nigra and adjacent ventral tegmental area (Kincaid 2001). The reported effects of hypothyroidism on $\mathrm{TH}$ are at variance and seem to be influenced by several factors including its nature of induction. Hypothyroidism by surgical thyroidectomy resulted in an increase in $\mathrm{TH}$ function (activity and mass) in the median eminence (Wang et al. 1989) and in some hypothalamic nuclei (Kizer et al. 1978) but did not alter it in the preoptic nucleus (Kizer et al. 1978), substantia nigra (Nakahara et al. 1976) and superior cervical ganglia (Wang et al. 1989). Hypothyroidism induced by PTU treatment caused an increase in $\mathrm{TH}$ activity in the median eminence of the rat (Kizer et al. 1978), a decrease in the anterior locus coeruleus and adrenal, and no changes in the posterior locus coeruleus and substantia nigra (Claustre et al. 1996). In the rat, 
A

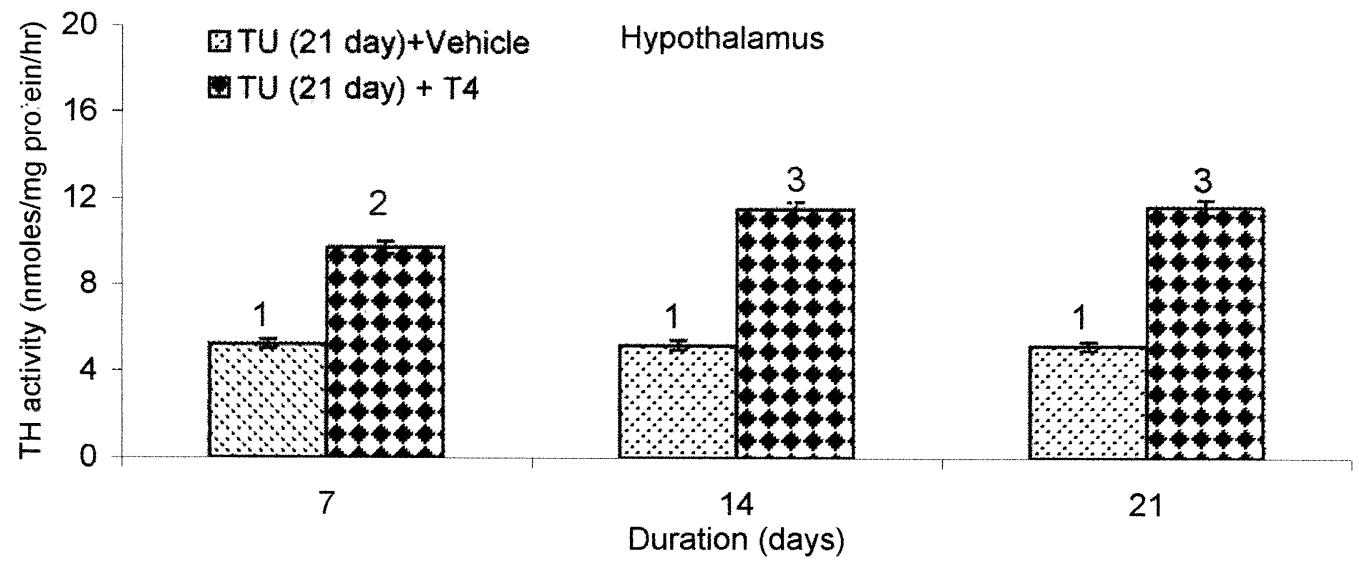

B

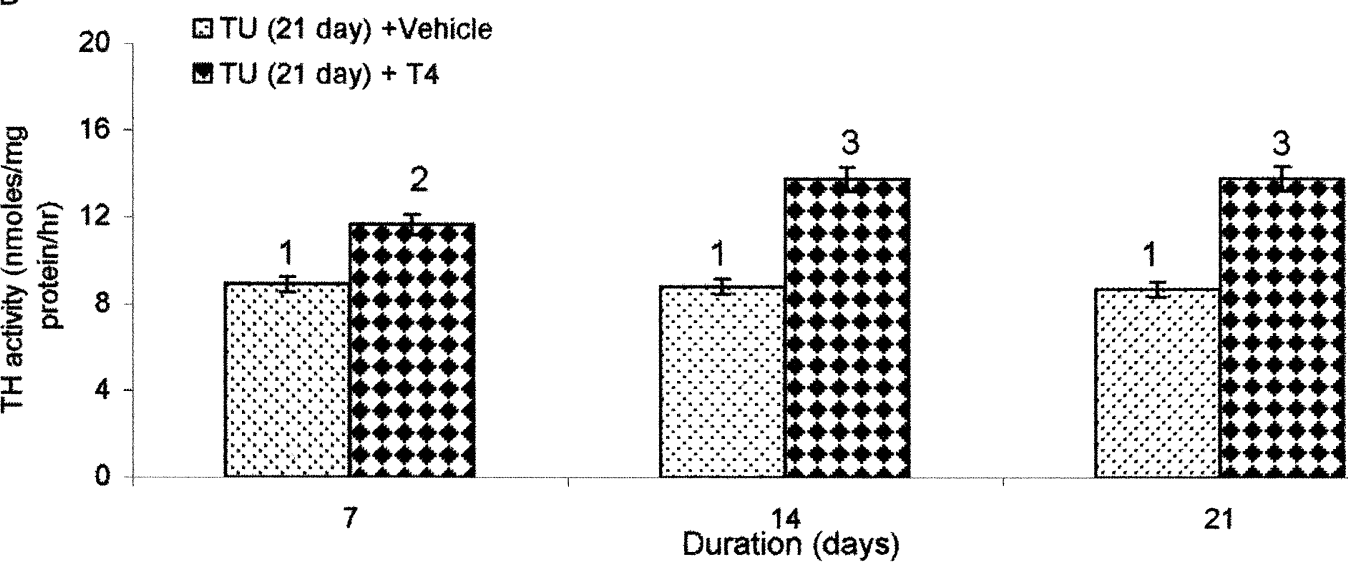

Telencephalon

C

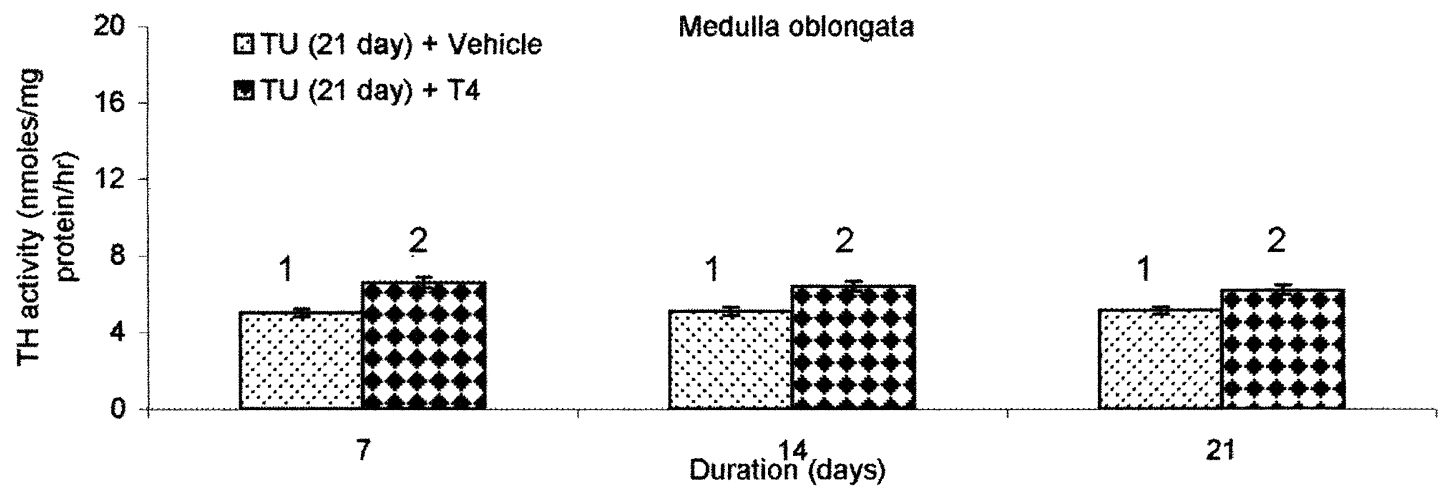

Figure 4 Effects of $\mathrm{T}_{4}$ replacement in the 21-day thiourea (TU)-treated female catfish Heteropneustes fossilis (means \pm S.E.M., $n=5)$ in the vitellogenic phase. Data were analysed by two-way ANOVA $(P<0 \cdot 001)$ and Newman-Keuls' test $(P<0 \cdot 05)$. Comparisons were made with respective controls and duration groups. Values with the same number are not significant and those with different numbers are significant in each experiment. 
neonatal hypothyroidism induced by PTU impaired $\mathrm{TH}$ activation in the adrenal and was reversed by $\mathrm{T}_{3}$ replacement (Valens \& Gripois 1990). The varied effects suggest that modulation of $\mathrm{TH}$ activity by $\mathrm{T}_{4} / \mathrm{T}_{3}$ is influenced by the interplay of other regulatory/modulatory signals as well. In the present study, catfish were rendered hypothyroidic by thiourea treatment, which resulted in a time-dependent significant decrease in serum $\mathrm{T}_{3}$ levels. In the hypothyroidic catfish, a duration-dependent significant decrease in $\mathrm{TH}$ activity was noticed in all brain regions in both seasons. The inhibition was higher in the forebrain regions than medulla oblongata with the telencephalic activity showing marked seasonal difference. The decrease in the GSI following hypothyroidism suggests decreased gonadal and $\mathrm{E}_{2}$ feedback activity and this may account for the higher inhibition of the enzyme in the vitellogenic phase. Claustre et al. (1996) reported decreased TH activity after PTU treatment, but Kizer et al. (1978) reported TH activation in rat brain nuclei. The thiourea-induced TH inhibition could be reversed by $\mathrm{T}_{4}$ replacement, but not by withdrawal of the treatment alone (vehicle control group). The data also showed that forebrain $\mathrm{TH}$ activity was more sensitive to the replacement treatment.

The kinetic data presented in this study may explain the changes in $\mathrm{TH}$ activity in relation to thyroid hormone excess and deficiency. The stimulatory effect of $\mathrm{T}_{4}$ appeared to be caused by a significant lowering of the apparent $K_{\mathrm{m}}$ value of the enzyme for the cofactor with concomitant increase in the apparent $V_{\max }$, as reported in thyroidectomised rats (Kizer et al. 1978). Thus, the stimulatory effect of $\mathrm{T}_{4}$ can be correlated to an increased affinity of the enzyme for the cofactor. In contrast, thiourea treatment (hypothyroidism) produced kinetic changes in the reverse manner and the TH inhibition could be due to a low affinity of the enzyme for the cofactor (high $K_{\mathrm{m}}$ and low $\left.V_{\max }\right)$. The thiourea-induced changes in the enzyme kinetics could be reversed by $\mathrm{T}_{4}$ replacement, resulting in a significant decrease in the $K_{\mathrm{m}}$ values and a significant increase in the $V_{\max }$. In contrast, Kizer et al. (1978) reported that PTU treatment decreased the $K_{\mathrm{m}}$ value for the cofactor and increased the $V_{\max }$, like surgical thyroidectomy. In hypothyroidic rat adrenal, the decreased TH activity was associated with an increase in $K_{\mathrm{m}}$ value in comparison with euthyroid animals (Blouquit et al. 1990). Thus, the stimulatory effect of thyroid hormones on $\mathrm{TH}$ activity may be mediated by the activation of the enzyme by kinetic changes. An increase in enzyme synthesis also may lead to increased $\mathrm{TH}$ activity. The thiourea treatment might have interfered with the enzyme activation and synthesis by decreasing the $T_{4} / T_{3}$ levels. Further studies are required to understand the molecular mechanisms involved in the modulation of $\mathrm{TH}$ activity by $\mathrm{T}_{4} / \mathrm{T}_{3}$.

In conclusion, brain $\mathrm{TH}$ is sensitive to the thyroid status; hormone excess activates and deficiency retards the enzyme activity by modifying its kinetic function. In turn, thyroid hormones can influence central CA-ergic activity and the dependent physiological processes such as osmoregulation, growth and reproduction in the catfish.

\section{Funding}

R C is grateful to the Council of Scientific and Industrial Research, New Delhi for the award of a senior research fellowship.

\section{References}

Blouquit MF, Valens M, Bagayoko A \& Gripois D 1990 Adrenal tyrosine hydroxylase activation in the developing rat: influence of the thyroid. Journal of Developmental Physiology 14 325-329.

Boularand S, Biguet NF, Vidal B, Veron M, Mallet J, Vincent JD, Dufour S \& Vernier P 1998 Tyrosine hydroxylase in the European eel (Anguilla anguilla): cDNA cloning, brain distribution and phylogenetic analysis. Journal of Neurochemistry 71 460-470.

Chaube R \& Joy KP 2002 Effects of ovariectomy and oestradiol-17 $\beta$ replacement on brain tyrosine hydroxylase in the catfish Heteropneustes fossilis: changes in in vivo activity and kinetic parameters. Journal of Endocrinology 175 329-342.

Chaube R \& Joy KP 2003 Brain tyrosine hydroxylase in the catfish Heteropneustes fossilis: annual and circadian variations and sex and regional differences in enzyme activity and some kinetic properties. General and Comparative Endocrinology 130 29-40.

Claustre J, Balende C \& Pujol JF 1996 Influence of the thyroid hormone status on tyrosine hydroxylase in central and peripheral catecholaminergic structures. Neurochemistry International 28 277-281.

Cyr DG \& Eales JG 1988 In vitro effects of thyroid hormones on gonadotropin-induced estradiol- $17 \beta$ secretion by ovarian follicles of rainbow trout, Salmo gairdneri. General and Comparative Endocrinology 69 80-87.

Denver RJ 1997 Thyroid hormone action in brain development: molecular biological aspects. In Advances in Comparative Endocrinology: Proceedings of the XIIIth International Congress of Comparative Endocrinology, pp 1071-1078. Eds S Kawashima \& S Kikuyama. Bologna, Italy: Monduzzi Editore SPA.

Diarra A, Lefauconnler JN, Valens M, Georges P \& Gripois D 1989 Tyrosine content, influx and accumulation rate, and catecholamine biosynthesis measured in vivo, in the central nervous system and in peripheral organs of the young rat, influence of neonatal hypo- and hyperthyroidism. Archives of International Physiology and Biochemistry 97 317-332.

Dratman MB, Crutchfield FL, Futaesaku Y, Goldberger ME \& Murray M $1987^{125}$ I triiodothyronine in the rat brain: evidence for neural localization and axonal transport derived from thaw-mount film autoradiography. Journal of Comparative Neurology 260 392-408.

Eales JG, Maclatchy DL \& Sweeting RM 1993 Thyroid hormone deiodinase system in salmonids and their involvement in the regulation of thyroidal status. Fish Physiology and Biochemistry 11 313-321.

Evans IM, Sinha AK, Pickard MR, Edwards PR, Leonard AJ \& Ekins RP 1999 Maternal hypo-thyroxinemia disrupts neurotransmitter metabolic enzymes in developing brain. Journal of Endocrinology 161 273-279.

Gordon JT, Kamins , DM, Rozanov CB \& Dratman MB 1999 Evidence that $3,3^{\prime}, 5$ - triiodothyronine is concentrated in and delivered from the locus coeruleus to its noradrenergic targets via anterograde axonal transport. Neuroscience 93 943-954. 
Gripois D \& Valens M 1984 Tyrosine hydroxylase induction in the young rat: control by thyroid hormones. Molecular and Cellular Endocrinology 38 87-89.

Hornby PJ \& Piekut DT 1990 Distribution of catecholaminesynthesizing enzymes in goldfish brains: presumptive dopamine and norepinephrine neuronal organization. Brain, Behavior and Evolution 35 49-64.

Kato T, Yamaguchi T, Togari A, Nagatsu T, Yajima T, Maeda N \& Kumegawa M 1982 Ontogenesis of monoamine-synthesizing enzyme activities and biopterin levels in rat brain or salivary glands, and the effects of thyroxine administration. Journal of Neurochemistry 38 896-901.

Kincaid AE 2001 Spontaneous circling behavior and dopamine neuron loss in a genetically hypothyroid mouse. Neuroscience 105 891-898.

Kizer JS, Humm J, Nicholson G, Greeley G \& Youngblood W 1978 The effect of castration, thyroidectomy and haloperidol upon the turnover rates of dopamine and norepinephrine and the kinetic properties of tyrosine hydroxylase in discrete hypothalamic nuclei of the male rat. Brain Research 146 95-107.

Linard B, Bennani S, Jego P \& Saligaut C 1996 Tyrosine hydroxylase activity and dopamine turnover of rainbow trout (Oncorhynchus mykiss) brain : the special status of the hypothalamus. Fish Physiology and Biochemistry 15 41-48.

Linard B, Pakdel F, Marmignon MH \& Saligaut C 1998 Cloning of a cDNA coding for active tyrosine hydroxylase in the rainbow trout (Oncorhynchus mykiss): comparison with other hydroxylases and enzymatic expression. Journal of Neurochemistry 71 920-928.

Lowry OH, Rosenbrough NJ, Farr AL \& Randall RJ 1951 Protein measurement with Folin-phenol reagent. Journal of Biological Chemistry 193 265-275.

Nakahara T, Uchimura H, Hirano M, Saito M \& Ito M 1976 Effects of gonadectomy and thyroidectomy on the tyrosine hydroxylase activity in individual hypothalamic nuclei and lower brain stem catecholaminergic cell groups of the rat. Brain Research 117 351-356.

Oppenheimer JH \& Schwartz HL 1997 Molecular basis of thyroid hormone-dependent brain development. Endocrine Reviews 18 462-475.

Plate E, Adams B, Allison W, Martens G, Hawryshyn C \& Eales J 2002 The effects of thyroxine or a GnRH analogue on thyroid hormone deiodination in the olfactory epithelium and retina of rainbow trout, Oncorhynchus mykiss and sockeye salmon, Oncorhynchus nerka. General and Comparative Endocrinology 127 $59-67$.
Puymirat J, Miehe M, Marchand R, Sarlieve L \& Dussault JH 1991 Immunocytochemical localization of thyroid hormone receptors in the adult rat brain. Thyroid 1 173-184.

Rastogi B \& Singhal RL 1976 Influence of neonatal and adult hyperthyroidism on behavior and biosynthetic capacity for norepinephrine, dopamine and 5-hydroxytryptamine in rat brain. Journal of Pharmacology and Experimental Therapeutics 198 609-618.

Rozanov CB \& Dratman MB 1996 Immunohistochemical mapping of brain triiodothyronine reveals prominent localization in central noradrenergic systems. Neuroscience 74 897-915.

Ruiz-Marcos A, Cartagena-Abella P, Martinez-Galan JR, Calvo R, Morreale de Escobar G \& Escobar del Rey F 1994 Thyroxine treatment and the recovery of pyramidal cells of the cerebral cortex from changes induced by juvenile-onset hypothyroidism. Journal of Neurobiology 25 808-818.

Schreiber G, Aldred AR, Jaworowski A, Nilsson C, Achen MG \& Segal MB 1990 Thyroxine transport from blood to brain via transthyretin synthesis in choroid plexus. American Journal of Physiology 258 338-345.

Senthilkumaran B \& Joy KP 1995 Changes in hypothalamic catecholamines, dopamine- $\beta$-hydroxylase, and phenylethanolamine$\mathrm{N}$-methyltransferase in the catfish, Heteropneustes fossilis in relation to season, raised photoperiod and temperature, ovariectomy and estradiol-17 $\beta$ replacement. General and Comparative Endocrinology 97 121-134.

Shiman R, Akino M \& Kaufman S 1971 Solublization and partial purification of tyrosine hydroxylase from bovine adrenal medulla. Journal of Biological Chemistry 246 1330-1340.

Timmermans LP, Chmilevsky DA, Komen H \& Schipper H 1997 Precocious onset of spermatogenesis in juvenile carp (Cyprinus carpio L., Teleostei) following treatment with low doses of L-thyroxine. European Journal of Morphology 35 344-353.

Valens M \& Gripois D 1990 Influence of neonatal hypothyroidism on adrenal tyrosine hydroxylase activation in the young rat. Clinical and Experimental Pharmacology and Physiology 17 371-376.

Wang PS, Gonzalez HA, Reymond MJ \& Porter JC 1989 Mass and in situ molar activity of tyrosine hydroxylase in the median eminence. Effect of thyroidectomy and thyroid hormone replacement. Endocrinology 49 659-663.

Received in final form 21 July 2003

Accepted 24 July 2003 